\title{
Homogamy Unmodified
}

\author{
Article published as: \\ Cohen, Philip N. 2011. “Homogamy Unmodified.” Journal of Family Theory \& Review 3 (1): 47-51. \\ doi:10.1111/j.1756-2589.2010.00080.x.
}

\begin{abstract}
I propose that homogamy and heterogamy be used to signify same-sex and opposite-sex unions respectively, including marriage and cohabitation. This is intended to address a terminology impasse that has given us "marriage" versus "same-sex marriage" in popular as well as academic usage. After a brief review of the word origins and scholarly uses of these terms, I conclude that the new uses for homogamy and heterogamy could be adopted relatively easily, with scientific benefits for categorization - and remove a conservative bias in the current usage.
\end{abstract}

\section{RUNNING HEAD: Homogamy Unmodified}

Studies of marriage have reached an uncomfortable terminological state. There is research on "marriage" (or other adult unions - hereafter all referred to as "unions"), and assumed to refer to unions between men and women, and there are studies of "same-sex marriage" (e.g., Frisch \& Bronnum-Hansen, 2009). Such a pattern, in which the normative or hegemonic case requires no specification while others carry a modifier, has been extensively critiqued in other areas - for example with regard to the "unmarked" nature of whiteness in race studies (Frankenberg, 1993) - and reflects an underlying heteronormativity (Danby, 2007) in the field. Additionally, opposing samesex unions with those that are opposite-sex highlights the tendency to refer to men and women as "opposite" sexes, which is also problematic (Ingraham, 1994; Scott, 1988). ${ }^{1}$

The larger categorical problem is that unions between partners of the same gender do not fit within the lexicon of family systems in the social sciences. For example, marriage (or equivalent) systems may be patrilineal or matrilineal, patrilocal or matrilocal, hypergamous, polygamous, and so on - all traditionally referring to patterns in the relationships between husbands and wives. None of these terms, as they are generally employed, may be applied to same-sex systems. To nudge this framework forward, bringing scientific terminology closer to social reality, I suggest that two existing terms - homogamy and heterogamy - be repurposed to signify same-sex and opposite-sex unions respectively, permitting balanced labeling of union types.

At this writing, seven countries permit the legal marriage of same-sex couples: Canada, Spain, South Africa, Sweden, Norway, the Netherlands and Belgium; as do some subnational units, such as Mexico City and Washington, D.C., and the U.S. states of Iowa, Massachusetts, Vermont, Connecticut and New Hampshire. In addition, legal recognition, with rights approaching those of heteragomous couples, has been extended in a larger group of countries, and various laws are being debated in many others (New York Times, 2009). ${ }^{2}$ With millions of legal unions attempted, accomplished or coming down the pike worldwide, unions that involve partners of the same gender require categorical integration into the family systems schema of the social sciences. 


\section{Homogamy and Heterogamy}

Homogamy and heterogamy descend from the Greek adjectives homo for "same" and hetero for "different," and gamos for "marriage" (OED, 1989). Perhaps their most logical application has been staring us in the face for 100 years, but could not be realized until unions between samesex partners began to be formally recognized in the last 20 years. ${ }^{3}$ Mirroring the uses of "homosexual" and "heterosexual," homogamy becomes "union between people of the same sex"; heterogamy is "union between people of different sexes"; and marriage, cohabitation or other union terms unmodified refer to the general cases. ${ }^{4}$

Homogamy was used initially for plants, then animals, and finally people. The Oxford English Dictionary records its first known use, in 1842, in reference to grasses that had florets all of the same sex; in 1854 it was used to mean hermaphrodite flowers with male and female organs. By 1874 homogamy was being used to refer to the condition in which "only individuals belonging to the same variety or kind are allowed to propagate," and, in a 1903 biology text: "preferential breeding between individuals similar in some characteristic." The OED records the first use of heterogamy in a 1862 history of a Hawaiian king who had one wife "educated for him from a child," but who also "may have had other heterogamous connections" - suggesting a contrasting lack of social status matching. ${ }^{5}$

The concept of homogamy has been of much greater interest to social scientists than heterogamy. The term's first appearance in the JSTOR database (about humans) is an 1899 reference to "the influence of homogamy on fertility" as a "problem relating to the evolution of man" (Yule, 1899-1900). An early occurrence in the American Journal of Sociology treats similarities in intellectual ability, published near the zenith of eugenics (Jones, 1929). Jones defined homogamy as "husband-wife similarity in a specific trait.” From his biological perspective, Jones wrote that homogamy, by "increas[ing] the average differences between subclasses of a population ... deserves to be considered with problems of social stratification and as a possible agency in accelerating or confirming evolutionary changes” (1929, p. 369) - the latter effect presumably resulting from the separate breeding of superior and inferior pairs.

In the last century, homogamy has been used for similarity between married or mating partners in such characteristics as education (Schwartz \& Mare, 2005), religion (Heaton, 1984) and race (Kalmijn, 1993), as well attitudes (Snyder 1964), phenotypic traits (Bodenhorn 2006), intellectual ability (Jones 1929), and many others. ${ }^{6}$ It is usually modified with the variable that identifies the similarity in question, e.g., "age homogamy" or "status homogamy."

Glaringly absent from this list is perhaps the most basic identity of all in modern society: sex or gender. Not that such a usage was never considered. Burgess and Wallin (1943, p. 109), after exhaustively reviewing evidence for which theory is more powerful, homogamy ("like marries like") or heterogamy, concluded: "On no trait except sex is there reliable evidence of predominance in marriage of dissimilars" (p. 109). In retrospect, they were being facetious - or naïve - because all studies at the time compared only opposite-sex couples, which according to the binary tradition of gender are considered perfectly dissimilar.

The many other aspects of partner similarity and difference clearly are worthy of study, and umbrella terms suggesting the tendency toward similarity or its absence are needed. I suggest the more logical "endogamy" for pairing within identity groups (such as ethnicities) - as used by Kalmijn (1998, p. 396) - and "assortative mating" or "assortative unions" for qualities that do not indicate group identities, such as age or personality, as is commonly used in stratification research and economics (Schwartz \& Mare, 2005). For preferences and attractions generally, of course, "homophily" remains central (McPherson, Smith-Lovin \& Cook, 2001).

An additional problem remains: the terms homogamy and heterogamy - just as "same sex" and "opposite sex" may presume the existence of two and only two sexes or genders. The proposed shift in terms does not resolve the issue of transgender identity and legal marriage or adult unions, although the use of "hetero" (different) is at least preferable to "opposite," and may serve the purpose in some situations. However, as has been the case, the burden remains on those who identify outside the binary sex/gender system to name their relationships as they seek social or legal recognition (Robson, 2007).

\section{Relationship Types Beyond Marriage}

I have included non-marital unions in the discussion to this point, although most uses of homogamy have focused on marriage. The cohabitation of unmarried partners in intimate relationships itself has been through a (still incomplete) terminological grinder reminiscent of that for marriage. The subject has spawned such awkward terms as POSSLQ, for "partners of the opposite sex sharing living quarters,” (Casper \& Cohen, 2000, p. 237) and now replaced by unmarried partner in U.S. Census terminology. ${ }^{7}$ Unlike marriage, which because of its legal status has safely implied opposite-sex status unless otherwise specified, cohabitation and dating seem more amenable to same-sex connotations (although many studies on cohabitation and dating never specify their implicit opposite-sex definitions).

The terms homogamy and heterogamy have at times also been used for non-marital relationships. In an early example, Kurdek and Schmitt (1987) describe as homogamy the similarity between same-sex as well as married and unmarried opposite-sex couples (although they refer to same-sex couple similarities as "partner homogamy.") Extending further from marriage, Blackwell and Lichter (2004, p. 19) refer to "homogamy and heterogamy along a continuum of commitment" from dating to marriage. On the other hand, non-gender similarity in many non-married 
couples has been studied without use of the term homogamy, including for example Jepsen and Jepsen (2002), who analyze matching outcomes among same-sex unmarried and opposite-sex married and unmarried couples. In sum, using homogamy and heterogamy for unions generally is reasonable, with specific modifiers for relationship type when needed.

\section{Conclusion}

In November 2008, California voters approved Proposition 8, which amended the state constitution to add a section reading, "Only marriage between a man and a woman is valid or recognized in California" (California Secretary of State, 2008). On the other hand, Mexico City has passed a law defining marriage simply as "the free uniting of two people" (Carroll, 2009, p. 19). The legal status of marriage and non-marital unions remains unsettled in many areas, but among substantial populations legal unions between same-sex partners are occurring - and informal unions are increasingly recognized socially. The common practice in the social sciences of referring to "marriage" without reference to its gender composition, in contrast to "same-sex marriage," effectively imposes a sort of scientific Proposition 8, in which "other" forms of union are discussed only when demarcated as in a different category.

With the social and legal situation in flux, it may be unrealistic to attempt a terminological turn at this point. And of course, terminology reform among academics does not necessarily have wider social impacts. For example, the Journal of Marriage and the Family changed its name to Journal of Marriage and Family in 2001, as some members of the National Council on Family Relations successfully argued that removing "the" would make the journal's scope more inclusive. ${ }^{8}$ The journal published no explanation for the change, which might have drawn public attention. Still, the attention generated by recent events presents an opportunity to bring language reform into the conversation, among researchers and the public at large.

The current uses of homogamy and heterogamy no doubt will have their adherents, but there are reasonable replacements for these terms. On the other hand, our science sorely suffers for a lack of gender-composition terminology with regard to adult unions. For continuity with past studies, homogamy and heterogamy may be used with modifiers - as in "educational homogamy." But for samesex unions, I believe homogamy - unmodified - is the better term.

\section{References}

Blackwell, D. L., \& Lichtner D. L. (2004). "Homogamy among dating, cohabiting, and married couples." Sociological Quarterly 45(4), 719-737.
Bodenhorn, H. (2006). Colorism, complexion homogamy, and household wealth: some historical evidence. American Economic Review 96(2), 256-260.

Burgess, E. W., \& Wallin, P. (1943). "Homogamy in social characteristics." American Journal of Sociology 49(2), 109-124.

California Secretary of State. (2008). Official voter information guide. http://www.voterguide.sos.ca.gov/textproposed-laws/text-of-proposed-laws.pdf (Accessed February 7, 2009).

Carroll, R. (2009). We do: Mexico City blazes trail with legalisation of same-sex marriage. The Guardian, December http://www.guardian.co.uk/world/2009/dec/22/mexico -city-legalises-samesex-marriage (Accessed December 23, 2009).

Casper, L. M., \& Cohen, P. N. (2000). "How does POSSLQ measure up? Historical estimates of cohabitation." Demography 37(2), 237-245.

Danby, C. (2007). "Political economy and the closet: heteronormativity in feminist economics." Feminist Economics 13(2), 29-53.

Frankenberg, R. (1993). White women, race matters: The social construction of whiteness. Minneapolis: University of Minnesota Press.

Frisch, M., \& Bronnum-Hansen, H. (2009). "Mortality among men and women in same-sex marriage: a national cohort study of 8333 Danes.” American Journal of Public Health 99(1), 133-137.

Heaton, T. B. (1984). "Religious homogamy and marital satisfaction reconsidered.” Journal of Marriage and Family 46(3), 729-733.

Ingraham, C. (1994). "The heterosexual imaginary: feminist sociology and theories of gender." Sociological Theory 12(2), 203-219.

Jepsen, L. K., \& Jepsen, C. A. (2002). “An empirical analysis of the matching patterns of same-sex and opposite-sex couples.” Demography 39(3), 435-453.

Jones, H. E. (1929). "Homogamy in intellectual abilities." American Journal of Sociology 35(3), 369-382.

Kalmijn, M. (1998). "Intermarriage and homogamy: causes, patterns, trends.” Annual Review of Sociology 24, 395-421.

Kalmijn, M. (1993). "Trends in black/white intermarriage.” Social Forces 72(1), 119-146.

Kernodle, W. (1959). "Some implications of the homogamy-complementary needs theories of mate selection for sociological-research.” Social Forces 38(2), 145152.

Kurdek, L. A., \& Schmitt, J. P. (1987). "Partner homogamy in married, heterosexual cohabiting, gay, and lesbian couples.” Journal of Sex Research 23(2), 212232.

McPherson M., Smith-Lovin, L., \& Cook, J. M. (2001). "Birds of a feather: homophily in social networks." Annual Review of Sociology 27, 415-444. 
Morris, R. J. (1996). “Configuring the bo(u)nds of marriage: the implications of Hawaiian culture and values for the debate about homogamy." Yale Journal of Law \& the Humanities 8, 105-159.

New York Times. (2009). "Same-sex marriage, civil unions, and domestic partnerships." http://topics.nytimes.com/topics/reference/timestopics/ subjects/s/same_sex_marriage/index.html (accessed March 3, 2010).

O'Connell, M., \& Lofquist, D. (2009). "Counting same-sex couples: official estimates and unofficial guesses." U.S. Census Bureau Working Paper. http://www.census.gov/population/www/socdemo/files /counting-paper.pdf (Accessed May 22, 2009).

O'Donovan, C. (2004). "The abominable and detestable crime against nature": A revised history of homosexuality \& Mormonism, 1840-1980. Published online at http://www.connellodonovan.com/abom.html (Accessed December 23, 2009).

Oxford English Dictionary. (1989, 2nd Edition). Oxford: Oxford University Press.

Parr, J. (2004). "Homogamy.” Catholic Insight 12(5), 7.

Robson, R. (2007). "A mere switch or a fundamental change? Theorizing transgender marriage.” Hypatia 22(1), 58-70.

Schwartz, C. R., \& Mare, R. D. (2005). "Trends in educational assortative marriage from 1940 to 2003.” Demography 42(4), 621-646.

Scott, J. W. (1988). "Deconstructing equality-versusdifference: or, the uses of poststructuralist theory for feminism." Feminist Studies 14(1), 33-50.

Snyder, E. C. (1964). "Attitudes: a study of homogamy and marital selectivity." Journal of Marriage and Family 26(3), 332-336.

Yule, G. U. (1899-1900). "On the association of attributes in statistics, with examples from the material of the childhood society." Proceedings of the Royal Society of London 66:22-23.

\footnotetext{
${ }^{1}$ The term "same-sex marriage" also goes against the preferred use of "gender" for social identification. "Same-gender marriage" has not caught on. In this essay I use "same-sex" and "opposite-sex" to conform to common usage.

${ }^{2} \mathrm{~A}$ list of jurisdictions and their relevant laws is maintained at: http://en.wikipedia.org/wiki/Status_of_same-sex_marriage ${ }^{3}$ Denmark legalized homogamous unions with the same rights and privileges as heterogamous marriages in 1989, which some cite as the first same-sex marriage law (Frisch \& BronnumHansen, 2008).

${ }^{4}$ There have been a few uses of homogamy in the debate on same-sex marriage (e.g., O’Donovan, 2004), at least one of which is an attempt to deny gay rights advocates use of the word marriage (Parr, 2004). This seems not only spiteful but futile, as the writer acknowledges that the Greek origin includes the word for marriage. Another older use occurs in a legal argument in favor of rights to same-sex marriage in Hawaii (Morris, 1996).
}

${ }^{5}$ Following the $O E D$ reference, the story appears on p. 165 of the 1866 edition of Hawaii: The Past, Present, and Future of Its Island Kingdom, by Manley Hopkins (London: Longmans, Green \& Co.).

${ }^{6}$ The Social Science Citation Index (as of March 2010) includes 131 articles with "homogamy" or "homogamous" in the title, the plurality of which (74) are in sociology journals, dating back to 1959.

${ }^{7}$ The U.S. Census Bureau currently converts all homogamous couples who report themselves as married into "unmarried partners," to comply with the federal Defense of Marriage Act. This accounted for $43 \%$ of those reported as "unmarried partners" in 2000 (O'Connell \& Lofquist, 2009). At the direction of the Obama administration, the Census Bureau has begun the multiyear process of integrating same-sex marriage into its surveys and tabulations.

${ }^{8}$ This account comes from personal communication with Robert Milardo, then the editor of JMF, and Stephen Marks, who initiated the change. 